\title{
EVALUATION OF THE CUTTING EDGE FAN-SHAPED DURING THE CUTTING PROCESS BY THE HYDRO ABRASIVE WATER JET
}

\begin{abstract}
This article presents the current state of hydro-erosion cutting and factors affecting the quality of cutting surface. The aim of this article is the evaluation of the fanshaped water spray pattern on the bottom cut edge by the hydro-erosion cutting based on selected parameters like cutting surface roughness and the distance between the inlet and outlet water jet. The results demonstrate that cutting speed had the largest influence on evolution of fan-shaped bottom of the cut edge because increasing cutting speed increases the values of both parameters mentioned above.
\end{abstract}

Keywords: hydro-erosion cutting, cutting speed, fan-shape, cutting surface quality

\section{Introduction}

The cutting process of the material by the high pressure hydro abrasive water jet consists in removing a material by the mechanic effect of a narrow abrasive water jet at a high rate. The abrasive is used to increase the rate and the final quality of the cut material process [1]. High rate hydro abrasive water jet is generated by means of a hydraulic pump creating high pressure water that is by means of 0.1-0.3 mm diameter water jet cutter transformed into high rate water. The water jet penetrates the workpiece, gradually loses its kinetic energy and skews [2]. The place where the water jet comes into contact with the cut material, gives rise to the reduction of the cut material by the controlled process. The result of such a process is a continuously cut material. Regarding the fact that a cut material is predominantly an abrasive with water, in the place where the material is cut, traces of the water jet effect in the cut direction and movement are visible. These traces of the water jet effect can be eliminated or even removed by the change of cutting parameters. Quality degrees of the surface topography introduced by KMT firm are also used in this article and are stated in five categories (Table 1). 
Table 1. Quality degrees of the surface topography

\begin{tabular}{|c|c|c|c|}
\hline Degree & Characteristic & $\begin{array}{c}\text { Roughness } \boldsymbol{R} \boldsymbol{a}_{\boldsymbol{H K}} \\
{[\mu \mathrm{m}]}\end{array}$ & $\begin{array}{c}\text { Roughness } \boldsymbol{R} \boldsymbol{a}_{\boldsymbol{D K}} \\
{[\mu \mathrm{m}]}\end{array}$ \\
\hline Q1 & dividing cut & $4.0-6.3$ & $\leq 40$ \\
\hline Q2 & rough cut & $\leq 4.0$ & $\leq 25$ \\
\hline Q3 & middle cut & $\leq 4.0$ & $\leq 12.5$ \\
\hline Q4 & quality cut & $\leq 3.2$ & $\leq 6.3$ \\
\hline Q5 & best cut & $<3.2$ & $\leq 3.2$ \\
\hline
\end{tabular}

$R a_{H K}$ - roughness in the top outline, $R a_{D K}$ - roughness in the bottom outline

Factors characterising the surface created by hydro erosion (surface of the cut edge) in relation to the quality and productivity hydro erosion process are stated in three categories [3]:

1) basic physical properties,

2) the technical factors influence effecting the hydro erosion process,

3) the technological factors influence on the hydro abrasive surface erosion.

Analysis of these factors and dimensioning of their optimal setting have an important influence on the quality of the operation of the technological process and the surface made by hydro erosion. During the process of material cutting by the high rate hydro abrasive water jet, the form of the device - water jet is changed [4]. At a distance of entering the water jet the cut material, the diameter of the water jet is expanded and diverted from the originally perpendicular water jet from its own axle. The size of the shape change that can be called curvature primarily depends on the rate of the device movement and the thickness and mechanical properties of the cut material. Energy decrease, resistance of the cut material and the movement rate are the basic factors affecting the characteristic shape of the device (water jet) in the cutting material $[5,6]$.

The curvature of the water jet is made in the opposite direction in comparison to the movement of the cutting head. The increasing of the deflection angle of the leaving water jet against the entering water jet is manifested in the worsening of surface quality that is expressed in the roughness of a new made surface and perpendicularity deflection of the material cut edge in the perpendicular direction to the cutting direction. Position of the place where the water jet enters the processed material is not compatible with the place where the water jet leaves the material. The place of the leaving water jet lags the place of the entering water jet. The lagging of the lower part of the water jet in comparison to the upper part is designated as ,,jet lag“; in the picture below (Fig. 1) designated as „L“. The size of the jet lag is in the region of tenth millimetre up to several dozen millimetres and is a natural sign of an economical cutting way $[7,8]$. 

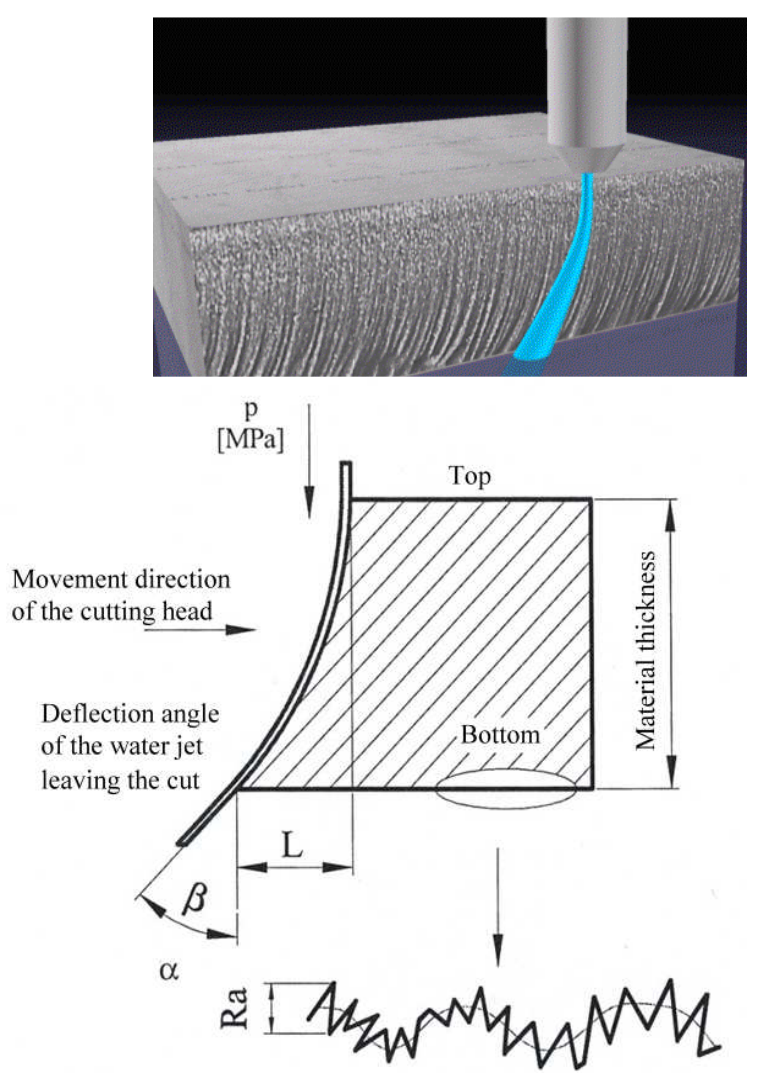

Fig. 1. Trace deflection of cut flag

\section{Material and testing}

In our research, test samples of stainless material STN 417240 , class 17240 - AISI 304 were used. This material represents chromium-nickel steel and, as to the anti-corrosive materials, it is the second most frequently used kind of material thanks to its resistance to corrosion, its cold forming and good welding property. The chromium-nickel steel is resistant to water, humidity, edible acids and weaker organic and anorganic acids. Temperature strain of this steel amounts to $300^{\circ} \mathrm{C}$. AISI 304 is well publishable and suitable to be used in operations of deep drawing, folding and curling. This material is also suitable for electric arc but unsuitable for blaze welding. Test samples with a depth of $15 \mathrm{~mm}$ were cut by the abrasive water jet device with a high pressure pump SL II 50K and two CNC X-Y tables of $3000 \times 1500 \mathrm{~mm}$, next AUTOLINE I cutting head and an abrasive (Bengal Bay Garnet). The other constants and parameters are stated in the tables. Test samples were cut in four phases: 
- perforation of the sample,

- $10 \mathrm{~mm}$ length cut from the perforation point (for the measurement of the cut boundary),

- sample cutting in the shape of a square (sides marked as $a, b, c, d$ ),

- each edge is cut at a different rate $(a=50 \mathrm{~mm} / \mathrm{min}, b=75 \mathrm{~mm} / \mathrm{min}$, $c=100 \mathrm{~mm} / \mathrm{min}, d=125 \mathrm{~mm} / \mathrm{min}$.

Samples were cut altogether and all diameters were written down into a collecting register of test samples cutting. 16 samples out of the total amount of 64 have been selected for the purposes of this study. The results of measuring and cutting have been recorded in the tables and evaluated with the help of graphs. For the evaluation of the fan-shaped of the cut edge by the hydro erosion, roughness measurements of the cut edge of samples and measurements of size distance between water jet entering and water jet leaving were carried out as representing parameters influencing the creation of the fan-shaped of the lower cut edge of the cut material. The following parameters have remained constant with each tested sample:

- abrasive - Bengal Bay Garnet (Mesh 80),

- water pressure - $300 \mathrm{MPa}$,

- abrasive jet $-\varnothing 1.02 \mathrm{~mm}$.

With regard to the extensiveness of the experiment, not all factors are stated; not all factor influencing the final quality of the cut surface as well as other evaluated parameters such as edge fanshaped and cut depth. Selected samples have been divided into 4 groups, each group containing 4 samples:

Group 1 - amount of abrasive $100 \mathrm{~g} / \mathrm{min}$; distance of water jet from material is $5 \mathrm{~mm}$.

Group 2 - amount of abrasive $150 \mathrm{~g} / \mathrm{min}$; distance of water jet from material is $3 \mathrm{~mm}$.

Group 3 - amount of abrasive $200 \mathrm{~g} / \mathrm{min}$; distance of water jet from material is $3 \mathrm{~mm}$.

Group 4 - amount of abrasive $250 \mathrm{~g} / \mathrm{min}$; distance of jet from material is $3 \mathrm{~mm}$.

The following parameters have remained constant with each tested sample:

- abrasive - Bengal Bay Garnet (Mesh 80),

- water pressure - $300 \mathrm{MPa}$,

- abrasive jet $-\varnothing 1.02 \mathrm{~mm}$.

With regard to the extensiveness of the experiment, not all factors are stated; not all factor influencing the final quality of the cut surface as well as other evaluated parameters such as edge fan-shaped and cut depth (Figs. 2-5). 
Fig. 2. Surface view of selected test samples cut with abrasive amount of 100 $\mathrm{g} / \mathrm{min}$

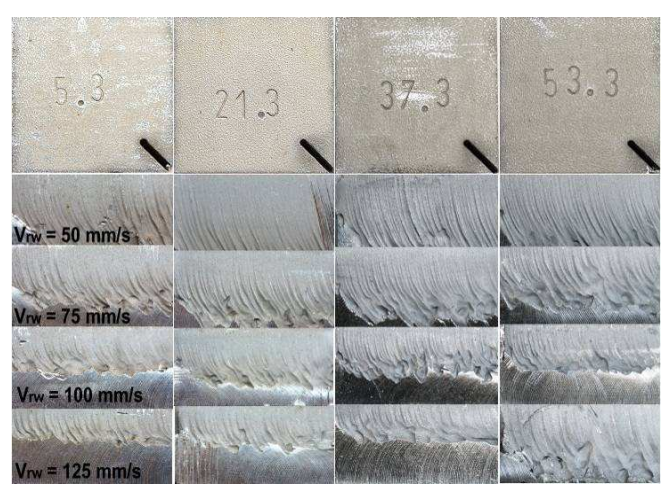

Fig. 3. Surface view of selected test samples cut with abrasive amount of 150 $\mathrm{g} / \mathrm{min}$

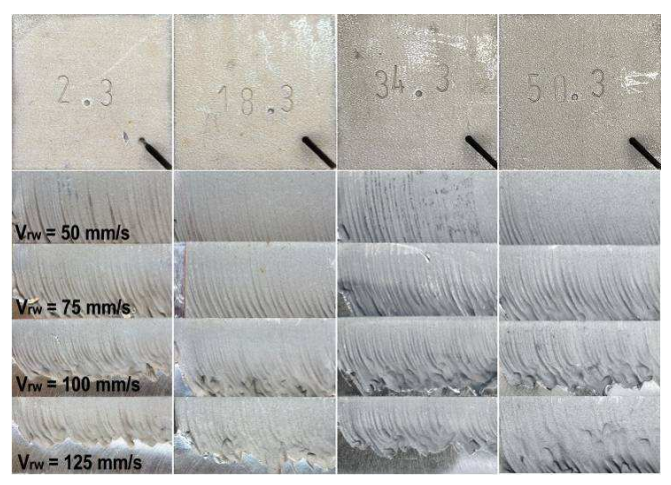

Fig. 4. Surface view of selected test samples cut with abrasive amount of 200 $\mathrm{g} / \mathrm{min}$

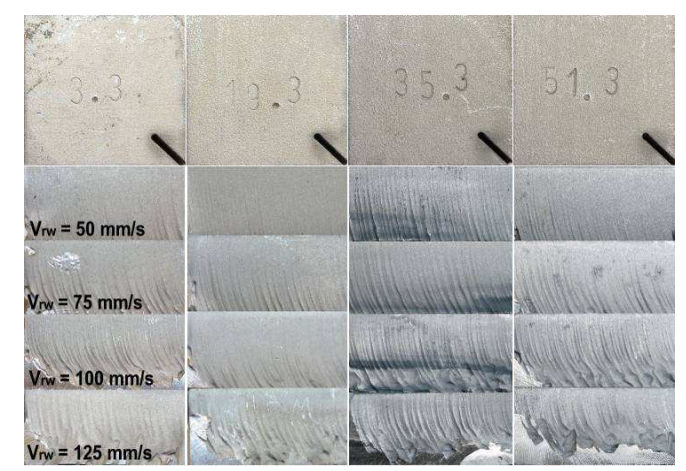




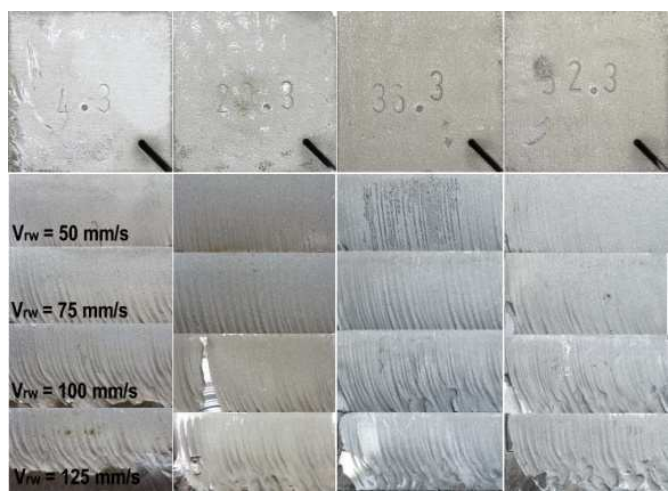

Fig. 5. Surface view of selected test samples cut with abrasive amount of 250 $\mathrm{g} / \mathrm{min}$

\section{Evaluation of the cutting edge fan-shaped}

A digital calliper Powerfix Profi has been used to measure and evaluate the intruded length of jet. The sample has been optically evaluated and the distance has been measured, by means of a calliper, in the most accentuated place of water jet entering and leaving (Fig. 6). The values gained have been written down into tables and evaluated by means of graphs (Figs. 7-10).

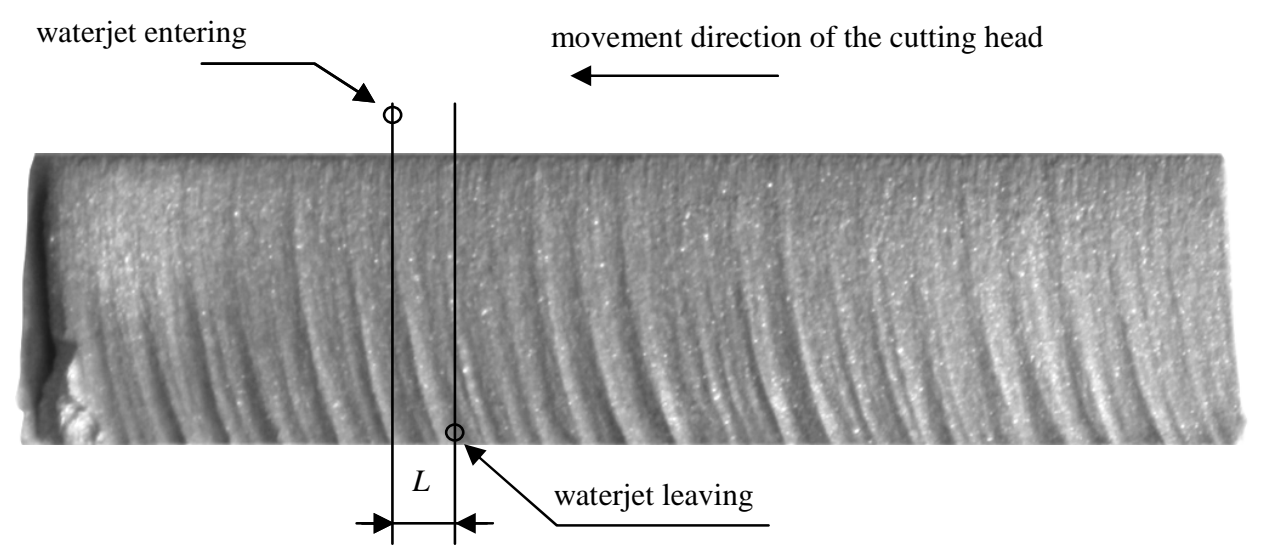

Fig. 6. Distance measurement between water jet entering and leaving

As it is shown in Fig. 7, the distance between input and output beam at a constant amount of abrasive $100 \mathrm{~g} / \mathrm{min}$ decreased with increasing cutting speed. This graph clearly shows that the cutting speed of $125 \mathrm{~mm} / \mathrm{min}$ is the optimum choice and cutting speed of $75 \mathrm{~mm} / \mathrm{min}$ is the worst possible because featheriness is the greatest. Next graph (Fig. 8) shows that a constant amount of abrasive at $150 \mathrm{~g} / \mathrm{min}$, the distance between the input beam and output beam 
appears as the best possible in cutting speed of $50 \mathrm{~mm} / \mathrm{min}$ and the worst possible choice would be to use a cutting speed of $100 \mathrm{~mm} / \mathrm{min}$, because the featheriness is the largest. Graphic evaluation of a constant amount of abrasive of 200 g/min (Fig. 9) clearly shows that the best used cutting speed appears cutting speed of $50 \mathrm{~mm} / \mathrm{min}$, where the distance between input and output beam is minimum. Opposite, proportionally increasing of featheriness using higher cutting speeds, that the highest cutting speed, $125 \mathrm{~mm} / \mathrm{min}$ seems like the worst possible because featheriness is the greatest. As in the previous graph, graphical evaluation at a constant amount of abrasive $250 \mathrm{~g} / \mathrm{min}$ (Fig. 10) shows that the increasing proportion of featheriness is based on increasing speed. We can conclude that for this quantity of abrasives, the most appropriate cutting speed seems

$50 \mathrm{~mm} / \mathrm{min}$ and as the worst possible speed is $125 \mathrm{~mm} / \mathrm{min}$ due to featheriness.

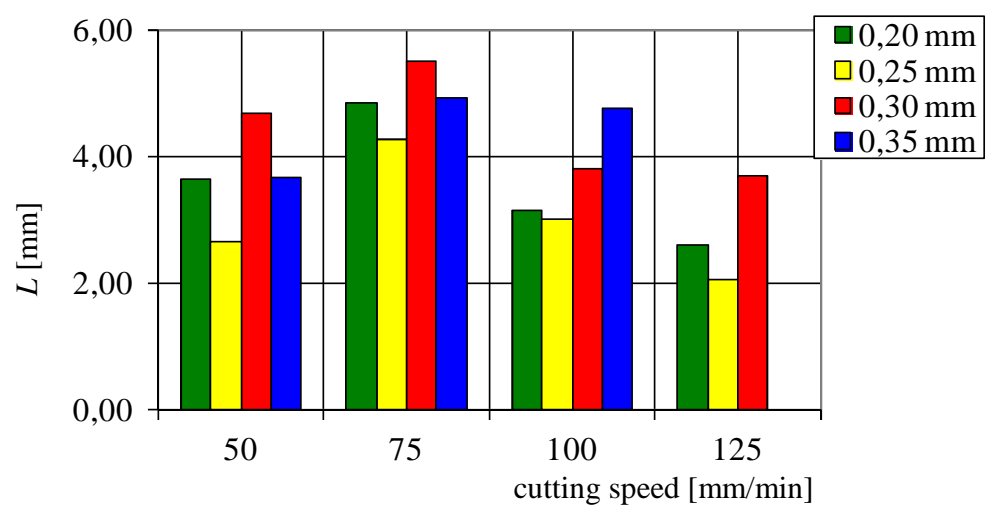

Fig. 7. The distance between water jet entering and leaving $L$ dependence on cutting speed and water jet diameter, with abrasive amount of $100 \mathrm{~g} / \mathrm{min}$

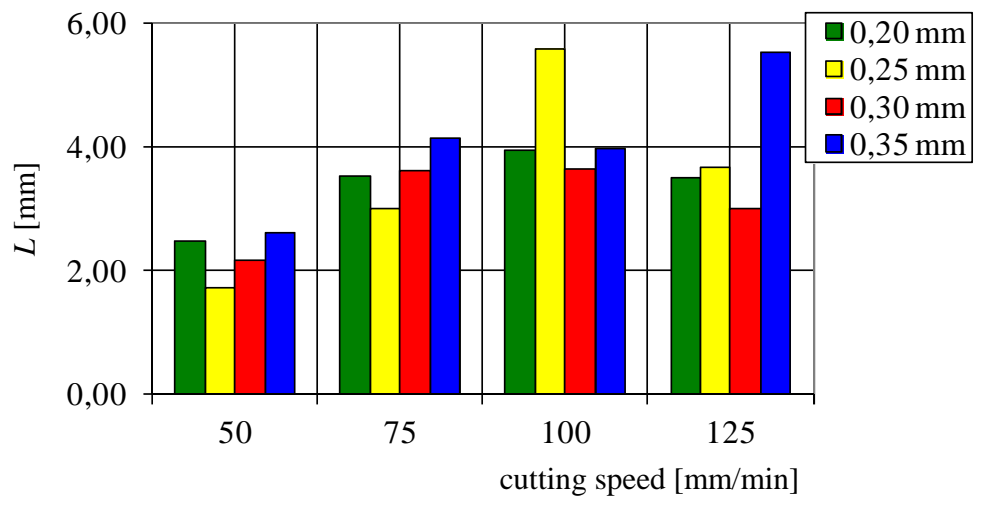


Fig. 8. The distance between water jet entering and leaving $L$ dependence on cutting speed and water jet diameter, with abrasive amount of $150 \mathrm{~g} / \mathrm{min}$

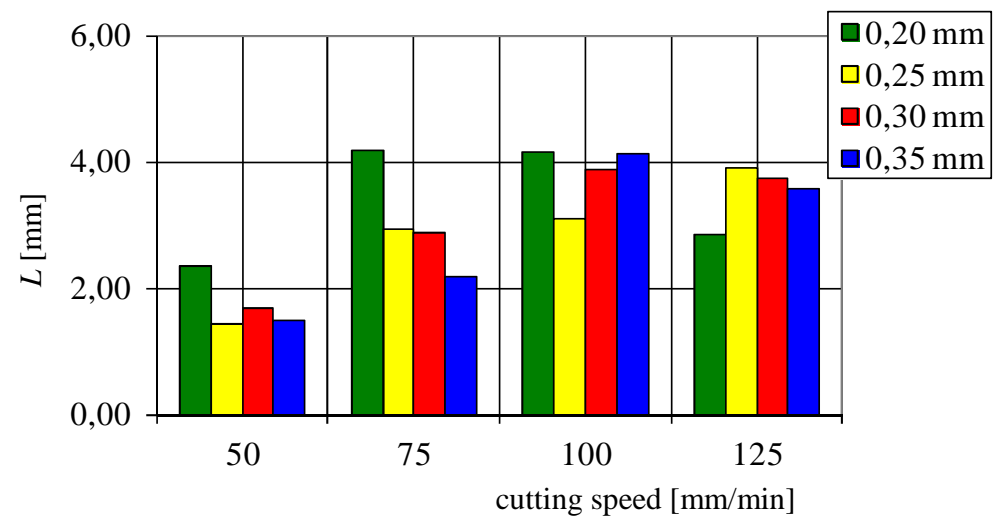

Fig. 9. The distance between water jet entering and leaving $L$ dependence on cutting speed and water jet diameter, with abrasive amount of $200 \mathrm{~g} / \mathrm{min}$

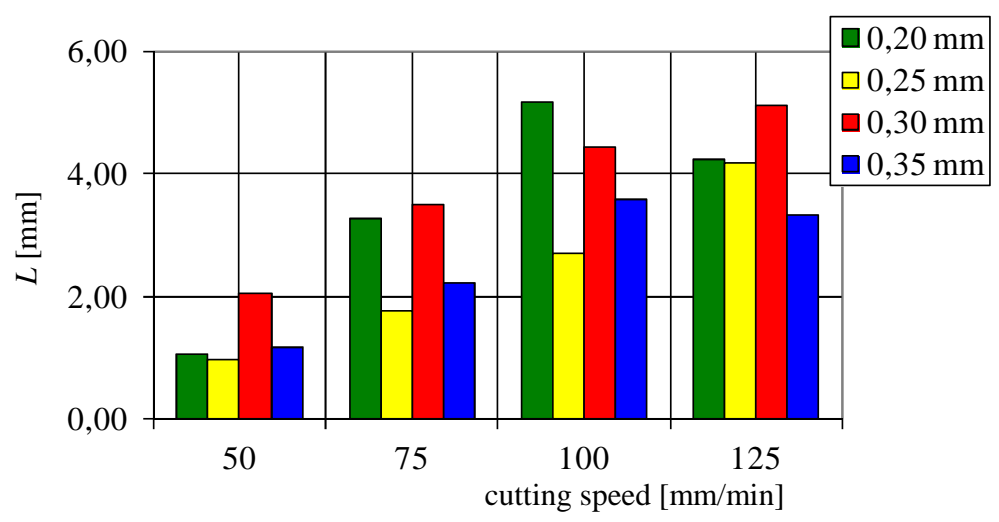

Fig. 10. The distance between water jet entering and leaving $L$ dependence on cutting speed and water jet diameter, with abrasive amount of $250 \mathrm{~g} / \mathrm{min}$

\section{Evaluation of the cutting edge roughness}

Roughness measuring was realized by Mitutoyo SJ-301 roughness measurement. The middle value was evaluated for $R a$ roughness for each side of evaluated samples. Roughness was evaluated with follow results:

1. At constant amount of grit $100 \mathrm{~g} / \mathrm{min}$, machined surface roughness has increased with increasing cutting speed (Fig. 11). At a cutting speed of 50 $\mathrm{mm} / \mathrm{min}$ roughness was soft and at a cutting speed of $125 \mathrm{~mm} / \mathrm{min}$ the roughness was harder. Finally we can conclude that this is maximum cut because the minimum value of Ra was $6.3 \mu \mathrm{m}$. 
2. The Figure 12 shows that a constant amount of grit $150 \mathrm{~g} / \mathrm{min}$ used at low speeds it seems to have positive effect on the soft roughness. Conversely, once again it confirmed that the rising rate negatively affects the roughness. We can conclude that this is maximum cut because the minimum value of $R a$ was $6.3 \mu \mathrm{m}$.

3. Using a constant amount grit $200 \mathrm{~g} / \mathrm{min}$, that for a given amount of abrasive there is a significant difference in roughness between the lowest and highest cutting speed (Fig. 13). Again, cutting speed of $50 \mathrm{~mm} / \mathrm{min}$ appeared to be optimal and cutting speed $125 \mathrm{~mm} / \mathrm{min}$ appeared as inappropriate. We can conclude that this is maximum cut, because of the smallest value of $R a$ that is in the range 4.0 to $6.3 \mu \mathrm{m}$.

4. The Figure 14 clearly shows that a constant amount of abrasives $250 \mathrm{~g} / \mathrm{min}$ appears again the lowest cutting speed $50 \mathrm{~mm} / \mathrm{min}$ is optimal and cutting speed $125 \mathrm{~mm} / \mathrm{min}$ as inappropriate. The highest values of the roughness but not as high as in the previous figures, when a smaller amount of abrasives was used. Nevertheless, we can conclude that this is maximum cut because the lowest value of $R a$ is in the range of 4.0 to $6.3 \mu \mathrm{m}$.

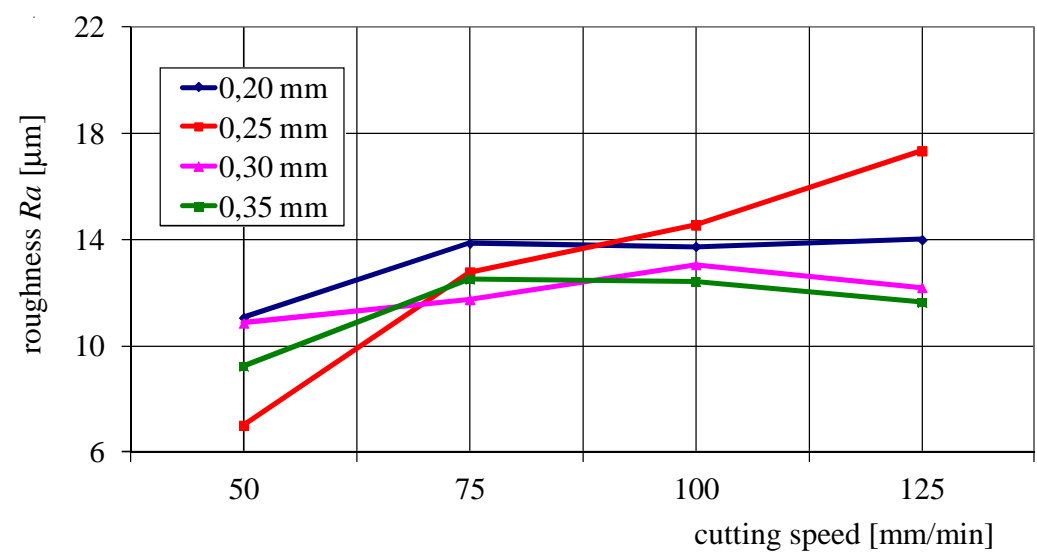

Fig. 11. The cutting edge roughness dependence on cutting speed and water jet diameter, at constant average abrasive nozzle $\varnothing 1.02 \mathrm{~mm}$, distance of nozzle from material $5 \mathrm{~mm}$, abrasive quantity of $100 \mathrm{~g} / \mathrm{min}$

Based on the evaluated results, it was found that the positive effect on the quality of the cutting edge has lower cutting speed and more abrasive. At a cutting speed of $50 \mathrm{~mm} / \mathrm{min}$ abrasives and weights of $200 \mathrm{~g} / \mathrm{min}$, the roughness ranged from 5.69 to 8.82 microns, which appeared to be optimal ratio selected. Negative impact on the quality of the cutting edge is a cutting speed, 
$100 \mathrm{~mm} / \mathrm{min}$ and $125 \mathrm{~mm} / \mathrm{min}$. Surface roughness at a cutting speed of 125 $\mathrm{g} / \mathrm{min}$ abrasives and weights $150 \mathrm{~g} / \mathrm{min}$ ranged between 18.2 to $21.21 \mu \mathrm{m}$.

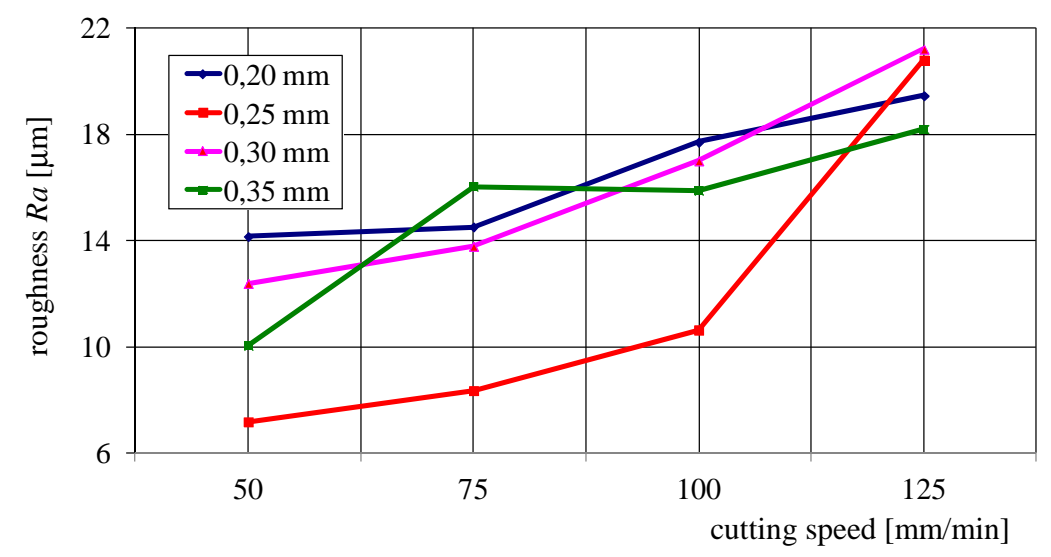

Fig. 12. The cutting edge roughness dependence on cutting speed and water jet diameter, at constant average abrasive nozzle $\varnothing 1.02 \mathrm{~mm}$, distance of nozzle from material $3 \mathrm{~mm}$, abrasive quantity of $150 \mathrm{~g} / \mathrm{min}$

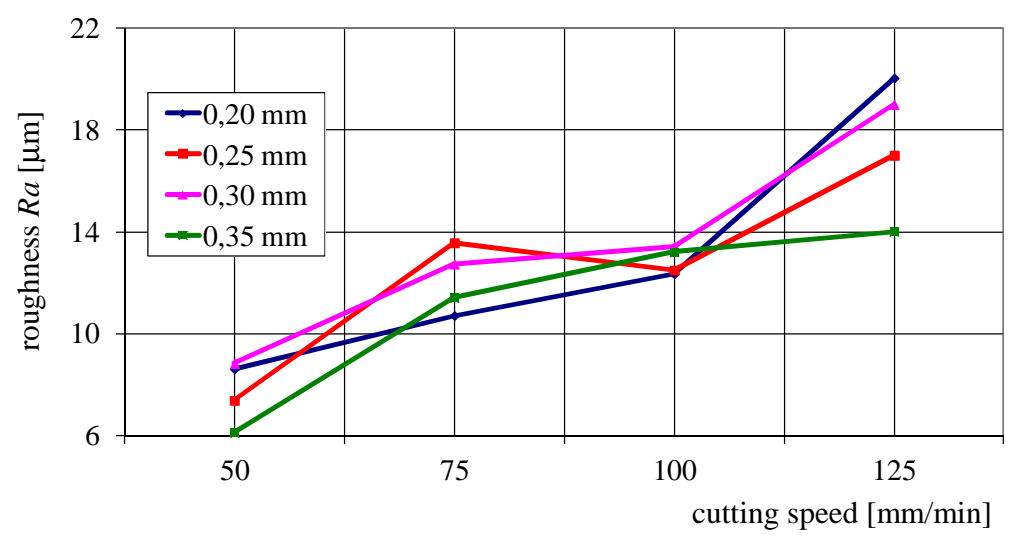

Fig. 13. The cutting edge roughness dependence on cutting speed and water jet diameter, at constant average abrasive nozzle $\varnothing 1.02 \mathrm{~mm}$, distance of nozzle from material $3 \mathrm{~mm}$, abrasive quantity of $200 \mathrm{~g} / \mathrm{min}$

\section{Conclusion}

Based on the evaluated results, it has been determined that the distance between water jet entering and water jet leaving decreased with the increasing abrasive amount and by following lower cutting rates. The increasing of a cut- 
ting rate negatively influences on the quality of the cut surface and the distance between water jet entering and water jet leaving, because the increasing of

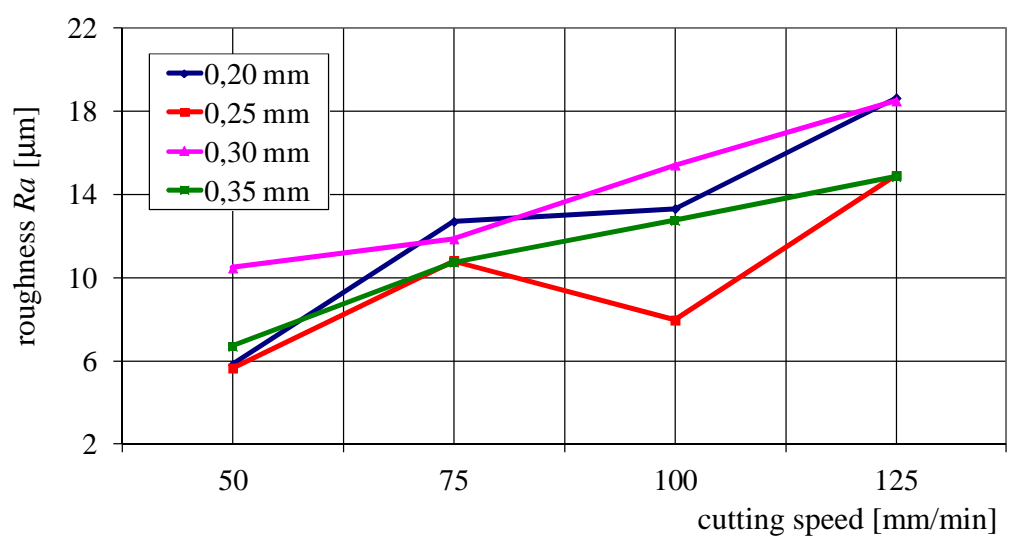

Fig. 14. The cutting edge roughness dependence on cutting speed and water jet diameter, at constant average abrasive nozzle $\varnothing 1.02 \mathrm{~mm}$, distance of nozzle from material $3 \mathrm{~mm}$, abrasive quantity of $250 \mathrm{~g} / \mathrm{min}$

a cutting rate increases also values of the mentioned parameters. As to the distance between water jet entering and water leaving, the abrasive amount of $200-250 \mathrm{~g} / \mathrm{min}$ at the rate of $50 \mathrm{~mm} / \mathrm{min}$ is considered to be optimal, but outside this range the influence of the abrasive amount impacts negatively, primarily on water jet entering and water jet leaving that has a direct influence on the cut edge fan-shaped. As an acceptable fan-shaped is considered the one visible to the naked eye because the bottom edge of the cut surface is no more relatively straight then.

\section{References}

[1] Maňková I.: Progresívne technológie: Advanced methods of material removal, Vienala, Košice 1999.

[2] Híreš O., Hatala M., Hloch S.: Delenie kovových materiálov okružnou pílou, vodným prúdom a plazmovým oblúkom, JIŘÍ PUSTINA, Ostrava 2007.

[3] Kmec J.: Vplyv parametrov vodného lúča na povrch vytvorený hydroabrazívnou eróziou, Vienala, Košice 2010.

[4] Sobotová L., Tkáčová J.: Progresívne technológie. Návody na cvičenia, TU, SjF, Košice 2008.

[5] Wilkins R.J., Graham E.E.: An erosion model of waterjet cutting, ASME J. Engng. Industry, 115 (1993), 57-61.

[6] Fabianová J.: Význam skúmania vplyvu rezných parametrov pri rezaní vodným lúčom, Výrobné Inžinierstvo, 2 (2007), 53-55 (online: http://web.tuke.sk/fvtpo/ /journal/pdf07/2-str-53-55). 
[7] Vasilko K., Kmec J.: Delenie materiálu, DATAPRESS, Prešov 2003.

[8] Waterjet machining tolerances: Limits to tolerance (online: http://waterjets.org/ /index.php?option=com_content\&task=view\&id=185\&Itemid=54).

\section{OCENA WACHLARZOWATOŚCI KRAWĘDZI CIĘCIA PODCZAS PROCESU CIECIA STRUMIENIEM WODNO-ŚCIERNYM}

Streszczenie

Artykuł przedstawia bieżący stan wiedzy na temat erozyjnego cięcia strumieniem wody oraz prezentuje wskaźniki, które wpływają na jakość powierzchni przecięcia. Celem artykułu jest ocena wachlarzowatości dolnej krawędzi powierzchni przecięcia na podstawie wybranych parametrów, takich jak chropowatość powierzchni przecięcia i odległość pomiędzy wlotem i wylotem strumienia wody. Wyniki badań wskazują, że prędkość cięcia ma największy wpływ na rozwój wachlarzowatości dolnej krawędzi powierzchni przecięcia, ponieważ zwiększenie prędkości cięcia zwiększa wartość obu wymienionych parametrów.

Słowa kluczowe: cięcie wodno-erozyjne, prędkość cięcia, wachlarzowatość, jakość powierzchni cięcia

DOI: $10.7862 / \mathrm{rm} .2012 .11$ 